\title{
Çevikliği Destekleyen Örgütsel Kültür Özellikleri
}

\author{
DOI: 10.26466/opus.525842 \\ Eyyüb Ensari Cicerali*
}
Dr. Öğr.Üyesi Nişantaşı Üniversitesi, İdari, İktisadi Sosyal Bilimler Fakültesi, Maslak / İstanbul / Türkiye
E-Posta: eyyub.cicerali@nisantasi.edu.tr
ORCID: $\underline{0000-0001-5943-9972}$

\begin{abstract}
Öz
İş hayatında değişen iş yapış şekilleri ile birlikte her geçen gün yeni yönetim yaklaşımları da önemini artırmaktadır. Değişen iş yapış şekilleri iş hayatının gün geçtikçe daha rekabetçi bir hale gelmesinin önünü açmaktadır. Çeviklik de özellikle dijital iş yaşamı ve dijitalleşen iş yapış biçimleri özelinde son zamanların en önemli iş konularından biridir. Yazılım, bilgi işlem literatüründe daha çok anılsa da çeviklik bir karakter özelliği olarak ele alınabilir. Çeviklik atik olma, çabukluk ve değişimlere hızla ayak uydurabilme özelliği olarak görülebilir. Bunlara ek olarak başarısızlıklardan ders alıp tekrar ayağa kalkabilmek de çevikliğin bir unsurudur. Rekabet hem kazanmayı hem de kaybetmeyi beraberinde getirir. İyi ve güçlü bir rekabete girişmek için çevik olmak başarı ve başarısızllıklara hazır olmak anlamına gelir. Örgüt kültürü çevikliğin ortaya çıkmasına izin verecek özellikleri ne kadar taşıyorsa bu özelliğin ortaya çıkması da o kadar kolay olacaktır. Bu makalede örgüt kültürü seviyesinde çevik iş kültürlerinin ne tür özellikleri olması gerektiğine yönelik yapılan gözden geçirme çalışmaları ele alınmış ve bu çalışmalar ışığında çevik iş kültürlerin özellikleri belirtilmiştir.
\end{abstract}

Anahtar Kelimeler: Çeviklik, Örgüt kültürü, Çevik iş kültürleri 


\title{
Cultural Characteristics That Support Agility At Organizations
}

\begin{abstract}
The term of culture has Latin origin "cultura" that means cultivation. It is generally used to define civilization. New and contemporary management approaches are gaining importance in organizations. Those developments and changing approaches lead businesses and make them more competitive. They can also be seen as products and results that increase competition in business. Digitalization, agility and agile organizations are very popular terms in today's workplace. Although those terms are mostly studied at software and IT literature, agility can also be seen as a characteristic of an organizational culture. Organizational culture is composed of organizational characteristics. Agility can be seen as being able to understand, act and move quickly in business. In addition to that definition, agility is standing up quickly after a failure. Competition brings success and it sometimes brings failure. Organizations should be ready for a competition by strengthening their agile characteristics. They should also adapt agility as a characteristic of their culture. In this article, literature on agile organizational culture is reviewed and generally accepted cultural traits of agile organizations are specified.
\end{abstract}

Keywords: Agility, Organizational culture, Agile organizational culture 


\section{Giriş}

21. yüzyılla birlikte teknolojideki gelişimlerin hayatın her alanını daha güçlü bir şekilde etkilediği görünür bir gerçekliktir. Ortaya atılan bir teorinin pratiğe dönmesi ve hayatımızı etkilemesi çok kısa sürelerde olmaktadır. Örgüt kültürleri bir takım sembolik düşüncelerden, ortak bir dilden, örgütsel ortamda öğrenilen sosyal normlardan, değerlerden, tutum ve davranışlardan oluşmakta ve yapılan işlerle ilgili durumlarda bireylerin kararlarını ve iş yapış tarzlarını etkilemektedir. Schein (2010) örgüt kültürünü oluşturan unsurları (a) iş gruplarında artarak oluşan kurallar, (b) örgüt üyelerini kapsayan ve onlar tarafından aktarılan iş iklimi unsurları ve (c) örgütün çalışanları ve müşterilerine karşı oluşturduğu politikaların temelinde yatan bakış açıları olarak tanımlamıştır. Diğer yandan yeni iş yapış tarzlarına uyum sağlamak bir gerekliliktir. Bazı örgütlere yeni iş yapış tarzları hemen adapte edilmekte ancak bir çoğu adaptasyon konusunda hemen harekete geçememektedir. Bir örgüt için iş yaşamını etkileyen alanlarda ortaya çıkan değişimlere uyum sağlamak ayakta kalabilmenin olmazsa olmaz şartıdır. Örgütlerin nasıl bir yapısı olduğu ve nasıl olması gerektiği sorusu uzun yıllar araştırmacıların üzerinde durduğu bir konudur. Ortaya atılan modeller çeşitli olsa da gelinen noktada uzun süreli durağan modellerden bahsetmek imkânsız hale gelmiş değişen iş koşullarına hemen uyum sağlayabilen farklı yapıların önemi ortaya çıkmıştır. Alışageldiğimiz hiyerarşik, yatay, dikey, fonksiyonel ya da matris organizasyonların örgüt yapısını tam olarak tanımlayamadığı bir örgüt dünyasında yapının kendisinden çok niteliğine bakmak ve ortaya genel olarak koyduğu ana davranış tarzına odaklanmak daha uygun görülebilir. Bu konuda ortaya çıkan son yaklaşımlardan bir tanesi çevik örgüt yapısı ya da çevik iş kültürüdür. 2000'li yıllarla birlikte çevik sistemler ve yapılar görünür şekilde iş hayatında öne çıkmaya başlamıştır (Dyba ve Dingsoyr, 2008). Son dönemde ise örgütsel çeviklik gün geçtikçe önemini artıran bir konu haline gelmiştir (Harraf vd., 2015).

\section{Örgütsel Çeviklik}

Örgütsel çeviklik bir örgütün çevresel değişimleri sezmesi, algılaması ve onlara etkin şekilde cevap verebilmesidir (Ashrafi vd., 20015). Çeviklik 
hepimizin anladığı şekliyle hızlı olmayı gerektirir. Türk dil kurumunun sözlüğünde çevik atik, kolaylık ve çabuklukla davranan anlamında ifade edilmiştir (TDK'da çevik sözcüğünün anlamı aratıldı). Örgütsel çeviklik ise iki ilişkili kavramla bağlantılıdır. Bu kavramlar tepkisel bir kavram olarak örgütsel adaptasyon ve proaktif bir yaklaşım olarak örgütsel esnekliktir (Sherehiy vd., 2007).

\section{Çevikliğe izin veren örgüt kültürü özellikleri}

Bireylerin hayatta sahip oldukları genel geçer özellikleri nasıl kişilik olarak adlandırılıyorsa örgütsel yapıların özellikleri de kültür yoluyla kendini gösterir ve tüm bu özeliklerin oluşturduğu yapıya örgütsel kültür denir. Örgütsel çeviklik bir organizasyonun çevresel değişimleri koklaması ve onlara etkin cevap verebilmesidir (Felipe ve ark., 2016). Her ne kadar kaynağ daha çok dijital ürünler, yazılım ve teknolojik içerik olarak düşünülse de çeviklik gerçekte bir karakter özelliğidir. Örgütlerin dijitalleşen dünyaya verdikleri bütünsel tepkileri çeviklik özelliği kapsamında değerlendirilir. Çevikliği ortaya çıaran örgütsel özellikler de bu özellikleri barındıran bir kültürün o örgütte halihazırda var olmasını gerektirir. Bir başka deyişli başarılı çevik uygulamalar geliştirme potansiyeli bazı örgütsel kültürler için diğerlerine oranla daha mümkündür.

Çevikliğin bir iş kültürü özelliği olabilmesi için o kültürün halihazırda bazı özellikleri kendiliğinden gösteriyor olabilmesi gerekir. Kısacası çevik olabilmek için bir takım karakteristik altyapının oluşturulması gerekmektedir. Strode ve arkadaşları çevikliğin bir metod olarak örgütlerde var olabilmesi için yaptıkları kaynak taraması sonucunda genelde ortaya çıkan örgüt kültürü etkenlerini birleştirmişlerdir (Strode vd., 2009). Bu etkenleri (1) öğrenmeye ve geribildirime önem vermek, (2) örgütteki iletişimin işbirliğine açık bir rekabet içeren ve güven verici şekilde olması, (3) ekip çalışmasına önem verilmesi, (4) örgütün esnek, katılımcı ve sosyal etkileşimi destekliyor olması, (5) proje yöneticilerinin aynı zamanda bir fasilitatör olması, (6) iş ortamının bireyleri güçlendiriyor olması, (7) işbirlikçi liderlerin olması ve (8) örgütün yüz yüze ve resmi olmayan iletişime açık olabilmesi olarak sıralamışlardır. Beck (2005) ise bir örgütün gerçek değerlerinin gizlilik, izole olma, karmaşıklık, karşılıklı saygıya önem vermeme gibi özelliklerden oluşması durumunda çevik uygulamalar için hiç 
de uygun olmayan özellikleri barındırıyor olacağından çevik bir hale gelemeyeceğini belirtmiştir.

Rizvi (2013) çevik pratiklerin örgüt içerisinde nasıl geliştirildiğine yönelik sistematik bir gözden geçirme çalı̧̧ması yapmıştır. Bu çalışmada özellikle çevik uygulamalar geliştirilirken örgütlerde en önemli unsurların iletişim, iş birliği, koordinasyon ve kültürel farklılıklara saygı olduğu belirtilmiştir. Bu çalışmada örgüt içi iletişim ve iş birliğini artırmaya yönelik bir altyapının önceden kurulmuş olmasının önemine de dikkat çekilmiştir. Bazı kültürel özellikler de çeviklik üzerine yazılan ve bu konuda bazı kurallar oluşturmayı hedefleyen Çevik Manifesto gibi belgelerde bulunabilir (http://agilemanifesto.org/principles.html). Bu belgelerde de işbirliği halinde çalışmanın, yüz yüze iletişim, kendini yöneten takımlar ve iş geliştiricilere gerekli çevresel koşulları sunabilmenin önemi çevik örneklerin geliştirilebilmesi için hayati önemde kabul edilmektedir. Devamlı ve ısrarlı ürün geliştiren, bununla tecrübesini artıran yapılar öncelikli olarak görülmektedir.

Çevikliği artıran örgüt kültürünün önemli özelliklerinden biri de hata yapmamaya gayret ederken hata yapmaktan korkmamaktır. Devamlılığın ve sürekliliğin altında böyle bir özgüven yatmaktadır. Geleneksel yöntemler ya da alışılmış yönetim tarzları genelde kontrolcüdür. Kontrolcü kültürlerde hata pek sevilmez. Üzerine gidilir, hata yapanlara yaptırımlar uygulanabilir. Belirsizlikler de bu tür kültürler de aynen böyledir, minimum belirsizlik olması istenir. İnsiyatif alabilmek zordur (Zammuto vd., 2000). Bu durumda olası olumsuzlukların önlenebilmesi için en başta örgüt liderlerine adaptif olabilme konusunda ciddi görevler düşmektedir (Chow and Cao, 2008). Eğer aşağıya inen bir yürüyen merdivende yukarı çıkmak isterseniz ki rekabet ve piyasa bu türden bir görüntü verir, yukarıya hızlı şekilde hareket edilmelidir. İnsiyatif alabilme, iletişimi artırma, risk alma, işleri delege etme gibi çevikliğin temelini oluşturan davranışların örgüt içinde ödüllendirilebilmesi liderlerin ukdesindedir.

Liderlerin bu kararları alabilmesi kültürel olarak çevik iş yapış tarzlarını kolaylaştıracaktır. Risk alabilmek potansiyel tehlikelere ya da belirsizliklere karşı karar alma becerisidir. Karar alma becerisi de bir takım farklı alışkanlıkların geliştirilmesini ve bazı özelliklerin öne çıkarılmasını gerektirir. Bu özelliklerin başında yeniliklere açıklık, öğrenmeye açıklık ve piyasayı takip edebilme özellikleri gelir. Bunlar olmadan karar almak riski 
en büyük olduğu haliyle kabul etmektir. Belki de işini şansa bırakmaktır. Diğer yandan karar alacak olanların piyasayı takip edebilmesinin bir gerekliliği de gerekli kaynaklara ulaşabilmektir. Bu kaynaklar sadece yazılı kaynaklar olmayıp bir takım sosyal kaynaklar ve sosyal ağlardır. Sadece lokal olarak değil global anlamda da gerekli sosyal kaynaklara erişimin sınırlı olduğu durumlarda alınacak kararlar eksik kaynaklarla verilmiş olur. Çeviklik doğru kaynakları kullanarak hızlı karar almayı örgütün de hızlı bir şekilde bu kararlara uyum sağlamasını gerektirmektedir. Karar alan kişinin yaşı ya da tecrübesinden ziyade söylediği şeylerin ne kadar doğru olduğu bunları hangi kaynak ve delillerle desteklediği önemlidir.

Başlanması gereken nokta; çevikliğin örgütler için bir lüks değil bir gereklilik olduğunun farkına varabilmekte yatmaktadır. Farkında olmak beraberinde bir aksiyona geçme arzusunu getirir. Devamında geçmişte yapılan ciddi hataların ne olduğunun üzerinden geçilebilir. Sadece hatalara değil başarılara da odaklanılabilir ve tüm bu örneklerde alternatif stratejilerin ne olabileceği tartışılabilir. Hataların üzerine gitmek ve onlardan ders almak, sadece başarılardan beslenmekten daha olumlu bir baş etme ve yönetme stratejisidir. Yalnızca başarılara odaklanmak daha büyük başarıların gerekliliğine inanmaktır ki bir önceki yaklaşıma göre daha olumsuz bir yönetim stratejisi haline gelebilir. Daha stresli ve yorucu bir iş ortamını beraberinde getirebilir. Bireyleri etik olmayan iş yapış yöntemlerine sevk edebilir.

Burada önemli olan bir diğer husus da yeni ve popüler olan terimlerin içini gerçekten doldurabilmektir. Bu anlamda örgüt kültürünün sadece yeniliklere açık olması yetmez. Daha kritik olan öğrenmeye açılık odağıdır. Örgütü oluşturan bireylerin daha önemlisi liderlerin öğrenmeye açıklık özelliği örgüt kültürünün de yeni yaklaşımları daha çabuk öğrenmesini sağlayacaktır.

\section{Sonuç}

Dijital uygulamaların artması ve teknolojideki değişimler örgütleri çevik yaklaşımlar konusunda daha uygun ortamlara dönüştürmüştür. Örgüt kültürü ile çeviklik arasında ilişki bir çok çalışmada ortaya konmuştur (Strode vd., 2009). Tüm bu gelişmeler yeni bir örgütsel yaklaşım gerektir- 
mekle birlikte bu tercih her örgüt tarafından kabul görmemektedir. Çağ1mız iş dünyasının olmazsa olmazı çevik yaklaşımların örgütün bir parçası olabilmesi için örgüt kültürünün uygun altyapıya sahip olması gerekmektedir. Öğrenme çevikliğini destekleyen kültürler hata yapmaktan korkmayan, risk almasını bilen bireylerin oluşturduğu kültürlerdir. Bu kültürlerde bireylerin karar verirken risk almaktan korkmamalarını getiren unsur gerekli kaynaklara erişim imkânlarıdır. Kültür özelliklerini örgütteki bireylerin özellikle de liderlerin özellikleri şekillendirir. Bu bağlamda liderlerin sadece yeniliğe değil öğrenmeye açık olmaları öğrenme çevikliğini destekleyen bir kültürün önemli bir bileşenini oluşturur. 


\title{
EXTENDED ABSTRACT
}

\section{Cultural Characteristics That Support Agility At Organizations}

\author{
Eyyüb Ensari Cicerali
}

Nişantaşı University

The term of culture has Latin origin "cultura" that means cultivation and civilization. In general, culture refers to the composition of symbolic thoughts, a common language and socially learned norms, values, attitudes, behaviors, and beliefs that influence individual and group behavior within a social unit. It is generally used to define civilization of human-beings from sociological perspective. Firstly it was only used for describing the similarities and differences of distinct societies. Culture is crucially important in business settings and in organizational behavioral perspective. Up until the last few decades, culture in business has been a neglected issue. Today, research, and experience has been recommending the importance of cultural fit in terms of organizational performance results. Defining the culture of an organization is not simple. Different researchers defined it in different ways. A prominent researcher of organizational culture Schein (2010) defines the components of organizational culture as follows:

- The norms growing in working groups

- The climate in the organization conveyed by members of the organization

- The main values of the organization such as product quality or price advantage

- The viewpoint that guides an organization's policy towards employees and customers

Sorensen (2002) studied the ways of corporate cultures names as harmony cultures affect performance in corporations. He tested the hypothesis that strong corporate cultures improve company performance. His analysis of companies revealed that companies with strong corporate cultures have high and stable performance than companies with weak corporate cultures. The observable content includes the behavior, rules, myths, 
stories, rituals, and language. The unobservable part of culture consists of non-written norms, perceptions, values, beliefs, and assumptions of the organization. Culture affects the processes and the ways of doing different tasks within the organizations.

In the contemporary era, new management approaches are gaining importance at organizations and becoming part of organizal cultures. Those developments and changing approaches lead businesses and make them more competitive. They can also be seen as products and results that increase competition in business. Digitalization, agility and agile organizations are very popular terms in today's workplace. Although those terms are mostly studied at software and IT literature, agility can is seen as a characteristic of an organizational culture.

Agility can be seen as to understand, act and move quickly in business. In addition to that definition, agility is standing up quickly after a failure. Competition brings success and it sometimes brings failure. Organizations should be ready for a competition by strengthening their agile characteristics.They should also adapt agility as a characteristic of their culture.

Rizvi (2013) studied and made a review on how agile practices develop in organizational cultures. This review shows that the most important issues in development of agile practices in an organization are communication, cooperation, coordination, and respect for cultural differences. In this study, it is also stated that a predevelopment of communication and coperation infrastructure at organizations is crucial when developing agile practices. Some cultural elements can also be found in documents such as Agile Manifesto which aims to form some rules on the subject (http://agilemanifesto.org/principles.html). Those types of documents also Show that cooperation among teams, face-to-face communication, self managed teams, and environmental factors that offer eligible work environment for business developers are important factors of agile work cultures. In agile cultures, developing business solutions in a resilient and continuous way and increasing experince by those practices are also seen as important characteristics of organization. Pople should not get highly anxious by the fear of making mistakes.

Traditional management practices can be seen as favoring controlling behavior. Mistakes are not welcome in controlling cultures. Ambiguity or uncertainty can also be taken as weak behaviors or weak cultures in those 
cultures. It is hard to take initiative for idea sor goals (Zammuto et al., 2000). In modern work cultures, management should take the duty for preparing the organization for ambiguous and uncertain business environment in a way that is adaptive and respectful for mistakes. Organizations should decide quickly on many business related issues and quick decision making is risky. Leaders should handle the responsibility for taking initiative, increasing and developing communication within their organization for agile practices.

Being aware of the need for agile culture is the starting point fo many leaders. It is a must and not a luxury for organizations. Getting and extracting positive experiences from mistakes, increasing the ways and content of feedback in departments, being able to have positive perpective for failures of the past foster agile behaviors in an organization. By repeating those behaviors organizations start to have habitual agile behaviors in the market.

\section{Kaynakça / References}

Ashrafi, N., Xu, P., Sathasivam, M., Kuilboer, J.P., Koelher, W., Heimann, D., Waage, F., (2005). A framework for implementing business agility through knowledge management systems: In Proceedings of the Seventh IEEE International Conference on E-Commerce Technology Workshops, CEC 2005 Workshops, Munich, Germany, IEEE: New York, NY, USA, 116-121.

Beck, K. ve Andres C., (2005). Extreme programming explained: embrace change. 2 ed., Boston: AddisonWesley.

Chow, T. ve L. Cao, A., (2008). Survey of critical sucess factors in agile software projects. The Journal of Systems and Software, 81, 961-971.

Dybå, T. ve Dingsøyr, T., (2008). Empirical studies of agile software development: a systematic review. Information and Software Technology, 50, 833-859.

Felipe, C., Roldan, J. L ve Leal-Rodrigez, L., (2016). An explanatory and predictive model for organizational agility. Journal of Business Research, 69, 4624-4631.

Harraf, A., Wanasika, I., Tate, K. ve Talbott, K., (2015). Organizational agility. Journal of Applied Business Research, 31, 675-686. 
Rizvi, B., (2013). A systematic review of distributed agile software engineering. Alberta: Athabasca University.

Schein, E.H., (2010). Organizational Culture and Leadership. 4th Edt.. JosseyBass, San Francisco, CA.

Sherehiy, B., Karwowski, W., Layer, J.K., (2007). A review of enterprise agility: Concepts, frameworks, and attributes. International Journal of Industrial Ergonomics, 37, 445-460.

Sorensen, J. (2002). The strength of corporate culture and the reliability of firm performance. Administrative Science Quarterly, 47(1), 70-91.

Strode, E. D., Sid, L. H. ve Tretiakov, A. (2009). The impact of organizational culture on agile method use, 42nd Hawaii International Conference on System Sciences.

“TDK'da çevik sözcügünün anlamı aratıldı”, (2018). Erişim adresi: http://www.tdk.gov.tr/index.php?option=com_gtsve arama=gtsve guid=TDK.GTS.5c0d80d74efff6.09136703, 03.12.2018.

Zammuto, R.F., Gifford, B., Goodman, E.A., (2000). Managerial ideologies, organization culture and the outcomes of innovation: A competing values perspective. In Handbook of Organizational Culture and Climate; Askhanasy, N.H., Wilderom, C.P.M., Peterson, M.F., Eds.; Sage Publications: Thousand Oaks, CA, USA, 2000.

\section{Kaynakça Bilgisi / Citation Information}

Cicerali, E. E. (2019). Çevikliği destekleyen örgütsel kültür özellikleri. OPUS-Uluslararası Toplum Araştırmaları Dergisi, 11(18), 2422-2432. DOI: 10.26466/opus.525842 